NBER WORKING PAPER SERIES

\title{
INEFFICIENCY OF CORPORATE INVESTMENT \\ AND DISTORTION OF SAVINGS BEHAVIOR IN JAPAN
}

\author{
Albert Ando \\ Dimitrios Christelis \\ Tsutomu Miyagawa \\ Working Paper 9444 \\ http://www.nber.org/papers/w9444 \\ NATIONAL BUREAU OF ECONOMIC RESEARCH \\ 1050 Massachusetts Avenue \\ Cambridge, MA 02138 \\ January 2003
}

\begin{abstract}
Alberto Ando passed away prior to the publication of this paper. An earlier version of this paper was presented at the Economic and Social Research Institute, the Cabinet Office on July 30, 2001 and at the NBER/CIRJE/EIJS/CEPR Japan Project Meeting held at Swedish Embassy, Tokyo, Japan, on Sept. 13 - 15, 2001. It was finally reviewed at the NBER/CIRJE/EIJS/CEPR Japan Project Meeting held at the Research Institute of Asian Development Bank in Tokyo, on March 18-19, 2002. We are grateful for careful and detailed comments from Fumio Hayashi, Charles Horioka, Anil Kashyap and Larry Meissner. We also wish to thank Monica Arellano for research assistance. Finally, we are especially indebted to members of the National Account Division, the Economic and Social Research Institute, Cabinet Office, for their cooperation and support in resolving a number of complex and intricate data problems. Ando was grateful for the support provided by the ABE Foundation in the preparation of this paper. The views expressed herein are those of the authors and not necessarily those of the National Bureau of Economic Research.
\end{abstract}

(C)2003 by Albert Ando, Dimitrios Christelis, and Tsutomu Miyagawa. All rights reserved. Short sections of text not to exceed two paragraphs, may be quoted without explicit permission provided that full credit including . notice, is given to the source. 
Inefficiency of Corporate Investment and Distortion of Savings Behavior in Japan Albert Ando, Dimitrios Christelis, and Tsutomu Miyagawa

NBER Working Paper No. 9444

January 2003

JEL No. E21, E22, G31, H60

\begin{abstract}
The value of corporate equity in Japan is dramatically smaller than that implied by the sum of the reproduction cost of accumulated investment and the market value of land owned by corporations (that is, the Tobin's average "q" is much smaller than unity). This discrepancy appears to result from the very low rate of return earned on corporate investment and also from the extraordinarily small and stagnant dividend payments. It has persisted at least since 1965, and its size has become progressively larger over time. If the value of corporate equity were sufficiently high to close the discrepancy, the net worth of the household sector would have been larger than its actual value by some 395 trillion yen in 1998. Such an addition to household net worth would have generated additional consumption demand of at least 15 trillion yen. This paper traces the development of this valuation discrepancy over time, and explores its possible causes. In the process, we prepare an alternative estimate of the capital stock and its depreciation to those offered in the National Accounts. The basic difference is that the depreciation rates underlying our calculations are substantially lower than those used in the Japanese National Accounts, and closer to values prevailing in the United States. The qualitative characteristics of our results, however, remain unaffected by the choice between these alternative estimates.
\end{abstract}

$\begin{array}{lll}\text { Albert Ando } & \text { Dimitrios Christelis } & \text { Tsutomu Miyagawa } \\ \text { University of Pennsylvania } & \text { Department of Economics } & \text { Research Fellow } \\ \text { and NBER } & \text { University of Pennsylvania } & \text { Japan Center for } \\ \text { (Deceased) } & \text { Philadelphia, PA 19104-6297 } & \text { Economic Research } \\ & \text { 2-6-1, Nihonbashi Kayabacho, } \\ & \text { CHUO-KU, TOKYO, } \\ & \text { 103-0025, JAPAN } \\ & \text { miyakawa@jcer.or.jp }\end{array}$




\section{Introduction}

Malaise and stagnation notwithstanding, Japan is a rich country and Japanese have substantial individual wealth. However, the data suggest that somehow the accumulated net worth of the household sector (excluding land) is smaller than its saving should have achieved. In an earlier paper (Ando 2002a), one of us examined this capital loss and attributed some three fourths of it to losses in the household sector holdings of corporate equity. In this paper we examine in much further detail the components of this loss and the features of the operations of Japanese corporations ${ }^{1}$ that can possibly lead to it.

The Japanese National Accounts are the starting point for a quantitative analysis, but the nature of some key measures complicates this. Other measures simply are not provided. Still, we believe that the available data and compelling circumstantial evidence support our propositions.

The most important problem we encountered during our investigations was the extremely high depreciation recorded in the Japanese National Accounts. Thus, we have constructed a series of capital stock and depreciation that conforms more closely to international practice.

After our data adjustments we find that the rate of return on assets in the corporate sector (whether or not land is included) is very low. Another way of expressing this is that there has been excessively large investment by the corporate sector in physical assets that seem to have low productivity or earning capacity. This idea of "excessive" investment is also borne out by the fact that the market value of the equity of the corporate sector is lower than the liquidation (or replacement) value (i.e. the market sees that the investment is of low quality). Another way to see the same point is to look at average Tobin's q (which is below one).

This low market valuation (and low quality investment) seems to arise because of the corporate governance structure that permits low dividend payments. Since the level of dividends is so small, and the historical pattern of dividends does not give any basis to

\footnotetext{
${ }^{1}$ Please note that our discussion of corporations is in the framework of the National Accounts, so we are looking at a much larger universe than just those firms that have equity publicly traded on stock exchanges.
} 
expect them to increase even when operating surplus and corporate profits after tax increase over time, there is no reason for the market to increase its valuation of corporate equities. Thus, households find themselves with very little value in their ownership of corporations, they are not rewarded for their saving, and this results in the small value of their net worth, other than from the value of their land. Faced with this situation, households continue to save a large fraction of their income in an attempt to increase their net worth to a satisfactory level.

In addition, these low dividend payments leave cash in the hands of firms, which are then able to continue to make more low productivity investments. In other market systems we would expect this to have been corrected by takeovers, which are very rare in Japan, as is well known.

The paper is organized as follows. Section 2.1 discusses the accumulation of net worth of the household sector while Section 2.2 examines land as a determinant of consumption behavior. Section 3.1 discusses corporate saving and dividend payments. The balance sheet and the capital loss of the corporate sector are discussed in Section 3.2. Corporate investment behavior and financing decisions are addressed in Section 3.3. Section 4 concludes.

\section{Accumulation of Net Worth by the Household Sector}

\subsection{Household Net Worth and Saving}

This section will present the capital loss incurred by the households in more detail than shown in Ando (2002a). ${ }^{2}$ Table 1 summarizes the accumulation of net worth by the Japanese household sector from 1971 to 1998. Details on the data are in Box 1 and the table notes.

\section{Box 1}

\section{Savings and Net Worth Data in Tables 1 and 7}

Parts A through D relate changes in the value of stocks to flows for four broad components of net worth. Changes in net worth components are not computed directly.

\footnotetext{
${ }^{2}$ Our results here are slightly different than the ones reported that paper due to small revisions in our calculations.
} 
Instead, they are related to the flow-of-funds data through a reconciliation calculation. One element of the reconciliation is changes resulting from general inflation. For three categories - reproducible tangible assets (A), non-reproducible tangible assets (B), and equities (D), this inflation loss is not shown separately because one sector's loss is not another sector's gain. Thus, the reconciliation is the result of the difference between the price index for the asset and the deflator for total consumption expenditures.

For financial assets (C), losses to creditors are gains to debtors, so the effects of general inflation are reported explicitly (line $\mathrm{C} 4$ ) rather than as part of the reconciliation entry (line C3). Specifically, we multiplied the initial stock by the rate of change of the consumption expenditure deflator and recorded the resulting amount as inflation gain (loss). What is left is recorded as reconciliation.

Flow is positive when assets increase more than liabilities, and is negative when liabilities increase more than assets. For non-reproducible tangible assets (B), the flow is primarily net purchase (sale) of land by the sector. These assets are mostly land, but also include timber, fisheries, and subsoil assets. The National Accounts Division assures us that these are at market value. We do not know exactly how the information is obtained, but we have no choice but to accept it.

The structure of the National Accounts requires that the sum of the net acquisition of all items on the balance sheet equals saving recorded in the flow part of the accounts plus net capital transfers received plus statistical discrepancy.

Part E brings together information for the flows and changes in stocks. For 197198 , the sector’s net worth increased some $¥ 1,535$ trillion in 1990 prices (row E1), whereas saving adjusted for net capital transfers and statistical discrepancy was about $¥ 940$ trillion (row E2 = F2+F3+F4). Thus, the household sector had a net capital gain of $¥ 595$ trillion (row E1 minus E2, which also is E3 + E4).

The overall gain is due entirely to land. Excluding land, overall capital losses were some $¥ 236$ trillion (row E1a minus E2a, which also is E3a + E4a). Most of this is the inflation loss suffered on net financial assets (row E4a). (Saving excluding land is F1 minus B2.)

Throughout most of 1971-98, the net financial liability of the government sector was very small. Most of the net financial asset position of the household sector was matched by the net financial liability position of non-financial and financial corporations. 
The inflation loss of the household sector, therefore, was largely matched by the inflation gain of the corporate sector.

Why did this inflation gain of corporations not appear as an increase in the value of corporate equity owned by the household sector? During most of this period, corporations retained substantial earnings, yet the household sector gained less than $¥ 40$ trillion in the value of corporate equity, far smaller than the accumulated retained earnings and capital gains of corporations combined. We believe this is one of the most unusual features of the Japanese economy. It may provide a clue to one of the causes for the low level of consumption by the household sector. We will therefore look carefully at the corporate sector and how its saving and accumulation of assets are related to the value of corporate equity outstanding.

\subsection{Land}

The household balance sheet is shown in Table 2, column (5) for 1998 (Tables for years 1970, 1980 and 1990 are available online at <www.nber.org/data-appendix/ando_et_al>). It is immediately apparent how big is the value of land as a share of household net worth. How the extraordinarily high price of land affects the saving behavior of the household sector and why one might want it to exclude from the net worth of that sector is the topic of this section. We believe that one gains more insight by excluding the land component of net worth. This is based in part on the fact that the household sector has been a small net seller of land throughout the period studied, 1971-98, and the proceeds were used to acquire other assets.

How Japanese households view land is another reason. For a typical family, the land on which its residence stands is both a major asset and definitionally makes the imputed consumption of housing services very high. Thus, it is probable that a family views a rise in the price of land as representing both an increase in its assets and a rise in the cost of living, the two off-setting each other. If families can routinely borrow using land as collateral, a higher price of land may facilitate additional consumption. However, consumer borrowing including mortgages appears to be very low in Japan, suggesting either that the market is not well developed or that consumers do not wish to borrow. We therefore believe that most families view net worth excluding land as what is available to them over time.

That said, there are families who own more land than they need for their residences or farms. For them, excess land is like any other asset that can be sold to finance consumption as the need arises. Thus, the value of land is part of their life-cycle 
net worth, and an increase in the price of land must be viewed as an addition to their resources. At the other extreme, for families who do not own any land and aspire to acquire it, an increase in the price of land is a significant increase in the cost of living without a compensating increase in their income. Although there are thus significant allocative consequences within the household sector, for the sector as a whole the responses of these two extreme groups to a change in price of land should largely offset each other.

We will now look at the literature on the effect of land on consumption. There are two studies we are aware of that offer evidence on the effect of an increase in the price of land on consumption.

Ogawa et al (1996) introduce into a consumption function three components of wealth held by households: liquid financial assets, net illiquid financial assets, and tangible wealth (an estimate of the value of land and residential structures). They find the coefficient of tangible wealth is very close to zero, and its standard error is larger than the estimated value of the coefficient. They conclude that consumption is not affected by tangible wealth held by households. Because they define tangible wealth as the sum of the value of land and an imputed value of residential structures, their result does not bear directly on the effect of the price of land on consumption. However, because more than two-thirds of the variance of the variable is due to variation in the value of land, and variation in the value of land is due almost entirely to price variations, we may view his result as generally indicating that consumption does not respond to land price variation.

More direct evidence is provided by Murata (1999). She estimates a time series consumption function in the error correction formulation. The log of the consumptionincome ratio is a function of, among other things, the ratio of wealth to income and the ratio of land price to consumption prices. She obtains a small but significant negative coefficient for the ratio of land price to consumption prices. This again suggests that an increase in the relative price of land is unlikely to increase the consumption-income ratio.

There are also two other studies we have looked at which are not helpful for our purposes.

Dekle (1994) is hard to interpret because he regresses the level of consumption on the price of land and the rate of growth of output by prefecture without controlling for the level of income or wealth. Thus, the price of land can easily be a proxy for a basic resource variable in his estimation.

Takayama (1992) runs a regression of consumption on different measures of wealth and finds that the coefficient of net real assets (which consist essentially of real estate holdings) has a small positive value but is also highly significant. However, this 
variable is non-zero only for homeowners. Thus, because he does not control for home ownership in his regression, its coefficient can represent the effect of home ownership rather than the effect of the value of real wealth.

Alone, none of the considerations reviewed above definitely justify focusing attention on net worth excluding land as a critical factor in determining the savingincome ratio, but together with the reasons given in the text, they provide reasonable support to doing so.

\section{Saving and Net Worth Accumulation by the Corporate Sector}

\section{1. Income Flows}

This section examines the saving and dividend payments of Japanese firms. It shows that they are not only exceptionally small but that they have also decreased over time, thus providing an explanation of the low valuation of the firms.

We must begin however by examining a variety of data problems that are present in the Japanese National Accounts and which can seriously bias any analysis of the corporate sector behavior.

First, both the "non-financial corporate enterprises" and "financial institutions" components include not just private businesses but public enterprises. It is impossible to separate them completely for years before 1990. This is also true of the total business sector, which includes unincorporated enterprises. With the new National Accounts based on SNA93, this is not a problem going forward, but it will remain for prior periods. Thus, it is impossible to study long-term patterns in the behavior of the private business sector.

Second, even using SNA93, the National Accounts report neither the compensation of employees nor the value-added of output by sector. Thus, it is very difficult to assess how productively labor and capital inputs are utilized. Because how total value added is distributed to the factors contributing to production is important to our analysis, we use the whole economy less agriculture, housing and government.

How depreciation is computed in the National Accounts is a third source of difficulties. Depreciation is the change in value of a productive asset "as a result of physical deterioration, normal obsolescence, or normal accidental damage" (SNA 1993, p.147, 6.179). This can be calculated in several ways. For example, US firms typically 
use different methods to compute depreciation for tax purposes and for financial reporting purposes. In the US national accounts, depreciation (also called the capital consumption allowance) uses uniform service lives and empirically based depreciation patterns (compared to a wide range of methodologies allowed under GAAP (Generally Accepted Accounting Principles) and the tax code) and current cost (compared to historic cost used for financial and tax reporting). The difference between this number and depreciation reported for tax purposes is called the capital consumption adjustment (hereafter CCAdj). ${ }^{3}$

Unfortunately, Japanese national income data historically do not include such a CCAdj. Rather, under SNA68 depreciation using the tax code's provisions for service lives and historic cost was reported. Under SNA93, beginning with 1990 data, an adjustment that reflects the difference between historic and current cost is computed, but tax-code lives are still used. Depreciation using the tax code is (intentionally) faster than actual values. Using historical cost leads to under-statement in periods of high inflation. Adjustments to a current-cost basis were included with other items in the revaluation account under SNA68, but cannot be separated out to adjust the reported depreciation series (see EPA (1978)). Thus we have to adjust the reported depreciation with our own estimate of the CCAdj, using a method similar to Hayashi (1986).

We can see the effect of depreciation in Table 3, which shows how value added is distributed to the factors contributing to production. Table 3 presents data for the United States and for Japan using both National Accounts and our capital stock and depreciation estimates. Which estimates are used makes a substantial difference in how one evaluates the sector's performance.

As we have just observed, the Japanese National Accounts do not provide information on either a measure of output or the compensation of employees for the corporate sector. We will therefore work with the whole economy less agriculture, housing and government. ${ }^{4}$

\footnotetext{
${ }^{3}$ See $<$ www.bea.gov $>$, click on Methodologies, and under "National programs" see "A Guide to the NIPAs", pp. M10-12.)

${ }^{4}$ Information on estimates of output and its composition for the housing sector were kindly supplied to us by the National Account Division, Economic and Social Research Institute, Cabinet Office. GDP for Japan reported here reflects our estimates of the distribution of the imputed banking services among sectors. The U.S. figures incorporate the distribution estimated by the BEA.
} 
First, let us compare the United States (Part A) to Japan using National Accounts estimates (Part B). The figures for 1970 are radically dissimilar, presumably because the Japanese economy was still in the process of a rapid transformation. It may also be because the data for this period are of lower quality, as the National Accounts only begin with 1970.

Over the entire period, there are a number of differences. The ratio of employee compensation to GDP (column 7) declined steadily in the United States, whereas it was increasing steadily in Japan. The ratio of operating surplus to GDP (column 8) was declining sharply and steadily in Japan, whereas there is no particular pattern for the United States.

Although the share of depreciation (column 6) was increasing during the 1970s and 1980s for both, it is much larger for Japan and continued to increase in the 1990s, whereas for the United States it stabilized. As for the capital-output ratio (column 9), there was a steady increase for Japan, and no particular pattern for the United States. The ratio of depreciation to capital stock (column 10) was increasing in the United States but falling in Japan.

It is hard to see how the difference in the depreciation rate (12\% in Japan vs. $8 \%$ in the US as shown in column 10) can persist when the technologies available in both countries are approximately the same. It is possible that when the Japanese economy was still going through its rapid transformation - that is, until the early $1970 \mathrm{~s}$ - depreciation did indeed proceed more rapidly in Japan than in the United States. It is further conceivable that this higher depreciation rate became incorporated into Japan's accounting practices and tax code, and thus has persisted even after the economy matured and "true" depreciation became roughly comparable to that for the United States. In such a case, rational managers presumably would not abandon capital stock before it was economical to do so. That would create a situation in which data for capital stock and depreciation are seriously biased relative to their true quantities.

To remedy this situation, we constructed a series for net capital stock and depreciation that uses current costs and empirically based depreciation patterns. Our series is based on depreciation rates suggested by Hulten and Wykoff (1981), as adapted 
to the Japanese case by Hayashi and Inoue (1991). We leave the National Accounts estimates for residential houses untouched. The details of our reconstruction are reported in Appendix 1 (available online at < www.nber.org/data-appendix/ando_et_al $>$ ), and results are recorded on Part $\mathrm{C}$ of Table 3.

Our estimate of the net stock of capital stock in 1998 is some $18 \%$ larger than the National Accounts estimate. Our depreciation estimate is some $16 \%$ smaller than the National Accounts estimate adjusted by us to reflect current costs. As a result, our overall depreciation rate for Japan during the 1990s is around 8\%, which is roughly two-thirds of the approximately $12 \%$ implied by the adjusted National Accounts data. A simple theoretical example of the consequences of assuming a depreciation rate much higher than the one that actually prevailed in the economy is in Appendix 2 (available online at $<$ www.nber.org/data-appendix/ando_et_al >).

If this accounting bias took place in the United States where the financial markets are well developed and investors are constantly seeking arbitrage opportunities, sooner or later the market value of equities would adjust to correct it. If the market value persisted in reflecting the biased accounting records, in the U.S., an attempt at a takeover of a firm would be likely to occur. In Japan, however, since corporations are seldom subjected to a takeover or merger challenge, such biased data may well be accepted in the equity market and persist for a long time. We believe that these accounting biases are some of the factors contributing to the creation of a large market valuation discrepancy in the Japanese corporate equity market, to be discussed later.

Having adjusted depreciation, let us now proceed to a review of the dividends and retained earnings of Japanese non-financial corporations and financial institutions. The reader is reminded that these sectors include both private corporations and public enterprises, and we are looking at this mixture. Our impression is that the size of public enterprises is especially large in the case of the financial institutions sector.

In Table 4, Part A and B, we present data for 1990 to 1998, using the revised National Accounts on the basis of the SNA93. We can't use data based on the SNA68 since the definition of dividends paid by financial institutions contained a number of items, including a part of imputed property income due to holders of life insurance policies, which swamped dividends paid to equity holders (see EPA (2000b)). The data 
based on the SNA93 give figures for dividends paid to equity holders separated from other payments, and the difference is very large. For 1998, gross dividends paid by financial institutions in the old accounts were 4.4 trillion yen, whereas they are only 0.7 trillion yen in the new accounts. For this reason, in this sub-section in which the income of equity holders is one of the central issues, we have no choice but to confine our discussion to the period 1990-1998, because the data on an SNA93 basis are available beginning only in 1990. Later in the paper, where it is essential to cover a longer period, we attempt to avoid dealing with dividends paid by financial institutions.

In addition, there are dramatic differences in the size of retained earnings of these two sectors between the old accounts and new accounts. These differences appear to be mostly due to changes in current transfers. We have not yet found specific references to this issue in the National Accounts Division's explanation of changes. We would, however, venture a guess that the Division changed the procedure for handling the writeoff of bad debts and that this is the main reason why there has been such a large change in current transfers and, hence, retained earnings.

Under these circumstances, it is extremely difficult to make coherent sense of these partial income statements for corporations. The best we can do is to offer a few observations that may be useful for future investigation.

(a) The net dividend payment by the non-financial corporate sector is steady at about 2.5 trillion yen per year (Table 4, line D). The payment of net dividends by financial institutions (line $\mathrm{H}$ ) is negative and around -0.3 trillion yen. Thus, these two sectors together paid other sectors of the economy, primarily the household sector and the rest of the world sector a total of 2.2 trillion yen in dividends per year during the period 1990 to 1998. This contrasts with dividend payments by American corporations (financial and non-financial combined) during the same period, starting at $\$ 144$ billion in 1990 and steadily increasing to $\$ 309.2$ billion in $1998 .{ }^{5}$ At an exchange rate of 120 yen to a dollar, American corporations paid roughly ten times the amount of dividends that were paid by Japanese corporations.

(b) If we accept the figures reported in the National Accounts, for the non-financial and financial corporate sectors combined, corporate retained earnings after tax (saving)

${ }^{5}$ As shown in Table 1.16 of the US National Income and Product Accounts. 
adjusted for CCAdj were close to zero for the period 1990 through 1995 as shown in Table 4. For the years 1996, 97, and 98, they were over 10 trillion yen. For the entire period 1990-1998, their average was about 5 trillion yen per year. If we replace the National Accounts estimate of depreciation by our own estimate, the retained earnings (saving with CCAdj) would be roughly 10 trillion yen greater per year, or around 15 trillion yen on average. This difference reflects the difference between depreciation with CCAdj given by the National Accounts and our own estimates, shown in Table 3, column (2). We can see the importance of making sure that the estimate of depreciation is reasonable and realistic. The retained earnings after tax with CCAdj and IVA (Inventory Valuation Adjustments) for U.S. corporations (nonfinancial and financial combined) fluctuate over time, but on average they are approximately $\$ 125$ billion per year. The Japanese figure is roughly one-third of the U.S. amount if we take the National Accounts estimate of depreciation, whereas it is about equal to the U.S. amount if we take our own estimate of depreciation.

(c) Even though we believe that Japanese corporations have retained more earnings and that their capital stock is probably larger than recorded, we suspect that the retained earnings of Japanese corporations have not contributed to the value of equities at all. One reason for our suspicion is shown in Table 5, where the historical record of the amount of dividends paid by non-financial corporations is shown. We have to rely on the data on the SNA68 basis here, since we wish to have a long time series. Therefore, we cannot work with the dividend payments of financial institutions. Since we do not have information on the output of corporations, we report private, non-farm, nonfinancial business GDP as the scale indicator. The most amazing fact is that nominal net dividend payments have hardly increased since 1970. In addition, there is a strange rise of dividends received from 1987 through 1995, making net dividends paid during this period extremely erratic and close to zero.

Retained earnings increase the value of equity, because they presumably contribute to increased profits and, hence, to future increases in dividends. In the case of Japanese corporations, however, the retention of substantial amounts of earnings by corporations, have not contributed to an increase in dividends at all. Thus, from the point of view of equity holders, retained earnings are of little value. Given the 
historical pattern of dividend payments, the market value of equity even at the end of the 1990's may be considered remarkably high. The average dividend-price ratio for those corporations listed at the Tokyo Stock Exchange, First Division, and paying dividends for 1998, 1999 and 2000 is reported to be $1.3 \%, 0.9 \%$, and $1.1 \%$ respectively (Bank of Japan (2002)).

We have noted that there are substantial differences in the pattern of dividend payments and retained earnings of non-financial corporations between National Accounts data on the SNA68 basis and data on the SNA93 basis. In Table 6, we report dividends paid and received according to the data on the SNA93 basis. The pattern is indeed different, especially in the period 1987-95 when the data on the SNA68 basis showed strange increases in dividends received. The pattern shown by the data on the SNA93 basis is perfectly smooth throughout the 1990's. The basic feature of the time pattern of dividend payments is common in both versions of data: dividend payments show no sign of growth to reflect the increasing scale of the economy over time.

We now turn our attention to the balance sheet of corporations and the relationship between the pattern of income and the structure of the balance sheet.

\section{2. Capital Accumulation by Corporations and the Valuation of Corporate Equity}

The consolidated balance sheet of the corporate sector is shown in Table 2, column (3). For those of us who normally operate outside Japan, there are some striking features. First, the value of land (see line (b)) is enormous, a substantial part of tangible assets. During the height of the asset bubble in 1987-91, its value even exceeded that of reproducibles. If it is added to the denominator of the ratio of operating surplus to fixed capital, the rate of return becomes minuscule. From the point of view of valuing a firm, there is no justification for omitting the value of land. In practice, however, a firm that has held land for a long time may not be using its true economic cost. Indeed, regardless of when the land was acquired and what was paid for it, there is no reason to account for its cost properly if management does not feel the need to compensate the firm's equity holders properly. 
Second, the net equity outstanding is a small fraction of the accounting net worth (defined in line (g) in Table 2) of corporations. When financial markets are functioning efficiently and expectations on the contribution of reproducible physical assets to earnings are realized, accounting net worth and the market value of net equity should be close, if not necessarily equal, to each other. However, in Japan they are not. Rather, there is a gap, which we term the market valuation discrepancy. This is calculated in Table 2, line (k). When the market valuation discrepancy is zero, the reproduction cost of reproducible fixed assets and the market value of land are fully reflected in the "value of the firm" (defined as the value of net equity outstanding plus net financial liabilities). Another way of saying this is that Tobin's average $q$ is one. When the value of land is very large, however, the interpretation of this concept becomes somewhat ambiguous, but we believe that the only tenable generalization of the concept is the inclusion of the value of land in the denominator. The value of q so computed is reported as line (m) in Table 2. For the consolidated corporate sector, it ranges from a low of 0.32 in 1980 to a high of 0.52 in 1998.

When the average $q$ is properly calculated, it is well known that its value can be reduced from unity, even in equilibrium, when the pattern of the depreciation allowance under the corporate profit tax system is accelerated relative to the pattern of economic depreciation (see, e.g., Gordon and Malkiel (1981)). However, it can be shown that the quantitative effect of this mechanism is quite minor, less than $5 \%$ of the reproduction cost of capital. Therefore, this consideration alone cannot account for the deviation of $\mathrm{q}$ reported in Table 2 from unity.

The possible reasons why the estimated value of q deviates so substantially from unity must be the same as those listed above for the very large value of market valuation discrepancy. ${ }^{6}$ When the market valuation discrepancy is negative and large, we are inclined to think of four possible reasons. One, for whatever reason, the price paid for the reproducible fixed assets is no longer justified in terms of the anticipated income stream

\footnotetext{
${ }^{6}$ Others have estimated the Tobin's average $q$, and Hoshi and Kashyap (1990) summarize them conveniently. Basically, estimates of $q$ using data from individual companies listed on the Tokyo Stock Exchange are close to unity, while those estimated using aggregate data are significantly less than unity. Both aggregate and micro data require many adjustments and imputations for the purpose of estimating $q$, and a satisfactory resolution of this paradox will require a large-scale data analysis. It may be noted that the
} 
it will generate. Two, there is a dramatic change in the value of land. Three, there may be serious imperfections in the capital market. Four, there is a deliberate policy by management to maintain the pattern of a very small and stagnant payment pattern of dividends. We consider the fourth reason as the most likely.

Let us recall the observation with which we ended the preceding section, namely, that dividend payments by these corporation are not only very small, but also that they have not increased much at all. Here we face a serious data problem, because dividend payment information in the National Accounts based on the SNA68 is not reliable, while the data based on the SNA93 is available only starting in 1990. We have no choice but to gain some sense of the pattern from these inconsistent data. Let us first look at the longer time series using the data based on the SNA68. Since net dividend payments by financial institutions are negligible, we can match net dividend payments of non-financial corporations reported in Table 5 and the market value of their net equity outstanding in Table 2. This dividend-price ratio averages approximately $2.6 \%$ for the period 1970 to 1998 , declining during the period. Thus, in the 1970 s it was $4.8 \%$, in the 1980 s it was $1.8 \%$, and in the $1990 \mathrm{~s}$ it was only $0.7 \%$. This ratio is remarkably low, given that dividend payments did not grow at all, whereas the scale variable increased by 7 times during the same period. For the 1990's, we can check this finding partially by using the data based on the SNA93. Dividend payments on this basis are given in Table 4, lines D and $\mathrm{H}$. The dividend-price ratio for 1999 is $1.9 \%$ (1.4\% for 1991), confirming the pattern given by the data based on the SNA68. Therefore, we conclude that at least a partial reason why the market value of equity is so low is that dividend payments have been extremely small and did not grow over time. This is a puzzling pattern. If the accounting net worth is correctly estimated in the NIA and the market value of equity is so depressed, in a well-functioning market, we would expect that someone would purchase the firm and liquidate its assets, realizing a major capital gain.

Table 7 traces development of the balance sheet for corporate capital stock in the same way Table 1 does for the household sector. Details on the data are in Box 1 and the table notes.

estimate of $q$ using all firms appears to be considerably smaller than the one using only manufacturing firms 
By definition, the sum of flow of funds by use (row D2) equals the total by source (given in F). Unfortunately, the statistical discrepancy entry (F4) is fairly large, but the most surprising item is net capital transfers received (F2). For 1991-98, these include the government bailout of firms in this sector, and it is nearly five times as large as accumulated retained earnings. It is also a sizable amount in the two earlier periods; we are not quite sure why.

Accounting equity (D1) is divided between the market value of equity (D5) and the market valuation discrepancy (D6). In the Japanese National Accounts (and in SNA93) the discrepancy is designated as "net worth". We believe that this designation is not only misleading but also gives users a wrong impression of the performance by corporations.

We find it surprising that the market value of these corporations increased by only $¥ 70$ trillion between 1971 and 1998 , whereas their accounting equity increased $¥ 472$ trillion, thereby increasing the market valuation discrepancy by $¥ 402$ trillion. Box 2 analyzes this gap further.

\section{Box 2}

Decomposing the Market Valuation Discrepancy Increase
Are starting point is the total of funds transferred from other sectors of the economy to
the corporate sector during 1971-98. This can be approximated using the data in Table 7
column 4.
$+\quad \begin{aligned} 280.6 & \text { Accounting equity flow (D2) } \\ -16.0 & \text { Statistical discrepancy (F4) } \\ 182.6 & \begin{array}{l}\text { Inflation gain (C4) (This is largely the counterpart of the } ¥ 217 \text { trillion } \\ \text { inflation loss recorded in the household sector account, Table } 1 \text { row }\end{array} \\ 479.2 & \begin{array}{l}\text { Total funds transferred to corporate sector. } \\ \text { If the sector is }\end{array}\end{aligned}$




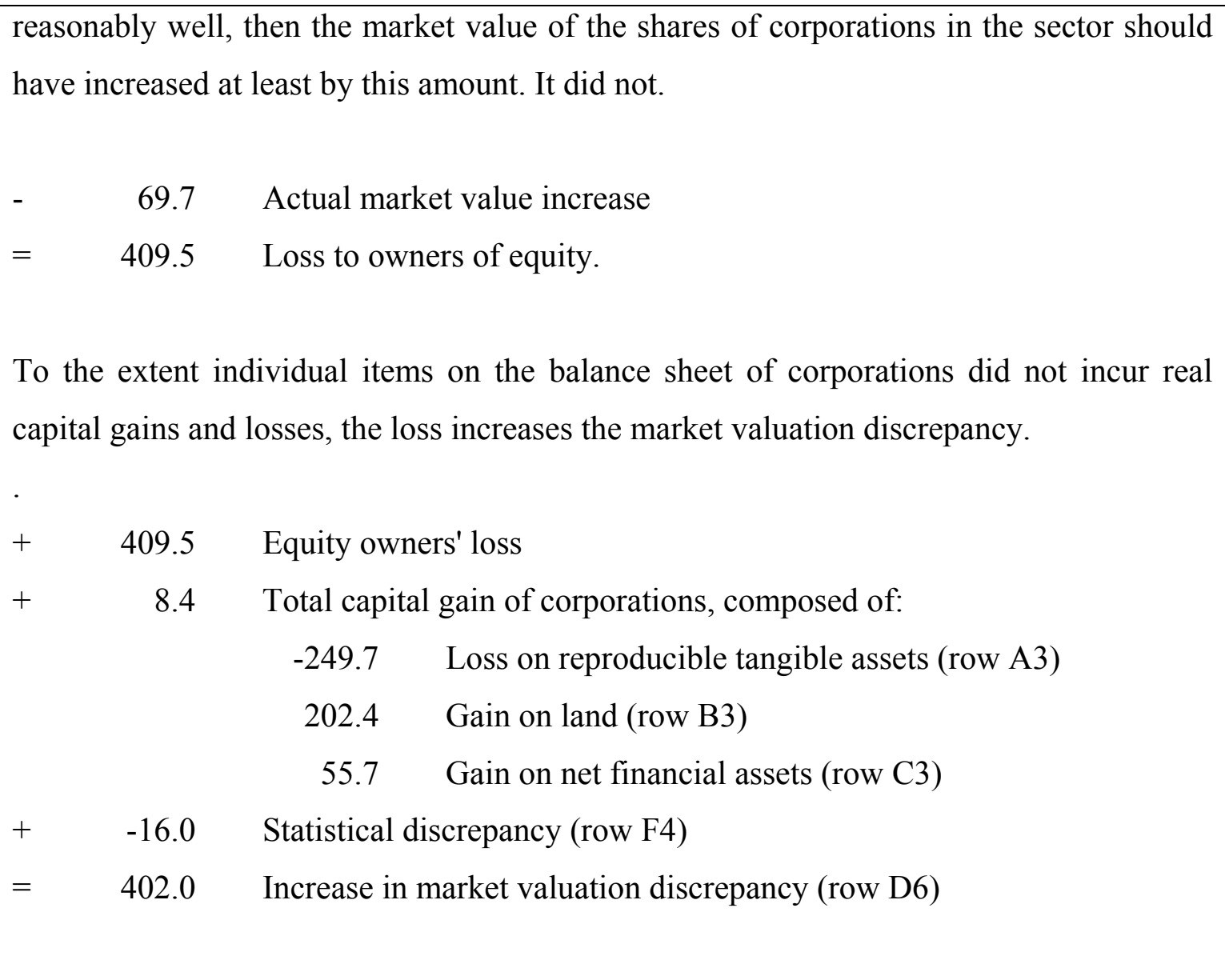

How does one explain the market valuation discrepancy? Part of the answer is that the corporate governance structure in Japan, management does not seem to feel any need to compensate equity owners. Thus, only token dividends are paid and scant attention is given to the market value of equity.

Management may have convinced itself that the token dividend payments define very low costs of internally generated funds, and thus investment in capital projects can be justified even when the expected rate of return is quite low. This is especially true if managers are encouraged to make their firms as large as possible, which is often said to be a goal of Japanese firms.

Beyond that, we believe that decision rules based on the management perception that the cost of internally generated funds contribute to other unusual features of the Japanese economy. These include a very high capital-labor ratio, a very low rate of return on capital for the corporate sector as a whole, and a dramatically small ratio of the market 
value of equity to the accounting value of firms. The puzzle is why new firms do not enter Japanese markets, follow the policy of efficient use of resources, and force older firms to reform. In any case, the apparent existing decision rules are an impediment to growth of the economy and the efficient allocation of resources.

This behavior may have historical roots. During the period immediately after World War II, most capital facilities were destroyed, obsolete, or both, so businesses needed to accumulate capital as quickly as possible to build plant and acquire new technologies. Thus, retaining as much of their revenue as possible for investment was a sensible policy, consistent with the needs of very rapid economic development. We suspect that the pattern of building as large a depreciation reserve as possible dates from this period. If corporations do not have to pay dividends to shareholders, the cost of internally generated funds is essentially zero.

Such behavior can be maintained only if the demand for output is growing rapidly, and if additional labor to match the rapid increases in capital is available. This was the case in the high-growth era, as Japan could shift a well-educated labor force from the agricultural sector to manufacturing and high-technology industries on a large scale, and its labor cost was lower compared to the United States and Germany. It was therefore able to price its products sufficiently low to expand its share of the market.

As demand and labor-supply growth slacken, the gross rate of return on capital gradually declines, and presumably it becomes near the level of depreciation. At that point, firms must begin to reduce the level of investment and distribute excess funds to holders of equity.

Such a point was reached quite some time ago in Japan, but firms continue as they have. In part this is because equity owners are in an exceptionally weak position to influence the policies of management. There are two related reasons for this.

First, Japanese law encourages corporations to enforce strict majority rule in the election of board members, rather than permitting cumulative voting. This means minority shareholders have very little leverage with management. Second, the tradition of cross-shareholding arrangements among corporations makes it extremely difficult for 
outsiders to form a majority. Managers who detect the prospect of a hostile majority group forming can quickly arrange for friendly corporations to increase their ownership. ${ }^{7}$

\section{3. Investment and Financing Decisions and the Rate of Return for Firms}

We have singled out the dividend payment pattern as a noticeably unusual behavior of Japanese firms. We can also observe from Table 3 that the operating surplus of the business sector in Japan appears to be a considerably smaller fraction of the value added less indirect taxes of the sector compared with the United States (15\% vs. 26\% in 1998). Let us now consider if there is some connection between these two observations. In Table 8, columns (1) and (2), we present the ratio of operating surplus to the value of reproducible and non-reproducible capital. The former is computed using our own estimate of depreciation, described in Appendix 1 and adjusted for imputed banking services, while in the latter the value of reproducible capital is our own estimate. We are not sure that our estimates for the years 1971 through 1973 are reliable. There may be something unsatisfactory about the estimates of the capital stock reported in the National Wealth Survey. Even starting from 1974, the rate of return on capital is quite low, and it declines steadily until it reaches a level of around $4 \%$ for non-financial corporations and $5 \%$ for the total business sector in the 1990's. Given that this rate is before the corporate profit tax, the rate of return is amazingly low.

This rate must be viewed as the measure of the marginal product of capital given the way it is computed. We are also interested in the rate of return accruing to the investor in the firm. We consider the investor who owns the equity and debt of the firm in the same proportion as the outstanding quantities. In Table 8, columns (3)-(5), we present the rate of return for such an investor. Column (3) is the ratio of dividends plus net interest payments to the sum of the value of equity and net financial liabilities. Column (4) records real capital gains and losses for the same base, and column (5) presents the total. This computation can be done only for the total corporate sector. The total rate of return is the amazingly low value of $2.91 \%$. The rate reported in Table 8 , column (5) is for all corporations and not strictly comparable with the one for non-financial

\footnotetext{
${ }^{7}$ In his chapter, Yafeh notes that minority shareholders have fairly good legal protection in Japan. This is true, and speaks to different issues. His concern is with how insider, usually majority, shareholders treat other shareholders. Our concern is with how management insiders treat all shareholders.
} 
corporations shown in column (1). Nevertheless, we should expect the one in column (5) to be smaller than the one on column (1), because the latter is the rate before corporate profit taxes, while the former is after corporate profit taxes.

Earlier in Table 3, we have noted that the capital-output ratio for the total business sector of Japan is much larger than the corresponding ratio for the United States, certainly in the 1990's. For 1998, the Japanese ratio is 2.06, whereas it is 1.48 for the United States. We are not including land in these calculations, so that the price of land is not involved. This is consistent with the fact that the rate of return for Japan is very low, much lower than the typical rate obtained by using the U.S. data. ${ }^{8}$

When a business firm's perception of the cost of one factor is unrelated to the price for that factor charged in the market, as it appears to be the case for equity capital for Japanese firms, we should expect that many decisions of the firm deviate substantially from those expected in the standard optimizing firms. Let us speculate on the investment and financing decisions perceived by a Japanese corporate manager in the simplest possible case, in which the firm cannot borrow, it does not need land, and there is no corporate profit tax. The manager wishes to finance his entire investment from internal funds every period, and he views his objective as increasing the size of the firm by a specific rate, $g$, indefinitely. This may not be a "rational" target, any other arbitrary targets produce similar results. He also knows that he has complete control of the internal funds, that is, he does not have to pay any dividends. He then must satisfy the accounting identity:

$$
\Delta K=\rho K
$$

where $\rho$ is the net rate of return on capital, that is, $\rho K$ is net income from the production process accruing to capital. Dividing both sides of (6) by $K$, we have

$$
g=\frac{\Delta K}{K}=\rho
$$

In writing (6a), we are assuming that the production function is homogeneous of first degree and that the productivity increase is labor augmenting. The rate of growth of output is then equal to the rate of growth of capital on the steady state growth path, and

\footnotetext{
${ }^{8}$ See Ando, Hancock and Sawchuk (1997).
} 
they are both equal to $g$. Let us suppose that the manager also believes he must satisfy the efficiency condition in the use of labor and capital:

$$
\frac{\rho+d}{w}=f\left(\frac{E}{K}\right)
$$

where $d$ is the depreciation rate, and $w$ is the wage rate, and $E$ is the number of hours worked. The manager views the net return on capital, $\rho K$, as available for the firm without cost, since the firm does not have to compensate equity owners. To satisfy (6a), then, he chooses $K / E$ so that the value of $\rho$ on the left-hand side of equation (7) becomes $g$.

The important point illustrated by this simple example is that the required rate of return on $K$ is not at all related to anything in the market. If $g$ is very small, the required net return on capital would also be quite small, and the capital-labor ratio would be correspondingly very large. The manager attempts to achieve an efficient combination of labor and capital from his point of view, but since the cost of capital is not related to the price of funds demanded in the market, his decision cannot be genuinely optimal.

Let us now consider a slightly generalized problem in which the firm is allowed to borrow, but still have to satisfy the modified version of (6):

$$
\Delta K=\rho K+\Delta L-r L
$$

or

$$
g=\frac{\Delta K}{K}=\rho+l(g-r)
$$

where $L$ is the loan taken out by the firm, $r$ is the rate of interest charged on $L$, and $l$ is the ratio $L / K$. Since the firm is not optimizing, there is no natural way to determine $l$, and we take its value as given. Then the value of $\rho$ is again determined by the identity (8a), and the capital-labor ratio is determined to achieve this value of $\rho$ through equation (7). This time, there is an additional complication that, if $\mathrm{r}$ is greater than $g$, there does not seem any sensible motivation to take out the loan. If a specific value of $l$ is viewed as required, however, a solution corresponding to it is feasible with $\rho$ being larger than $g$. 
As we have noted earlier, this is not an interesting or believable model of the behavior of a business firm. It does illustrate, however, the point that once the perceived price of a factor is not related to its market price, it is difficult to write an optimizing model, and a number of strange consequences can follow. For a firm whose behavior is characterized by (7) and (8a), it is perfectly conceivable that its target rate of return, $\rho$, is extremely low, and that the capital-labor ratio turns out to be very large. Its behavior is not efficient in the normal sense, and the true cost of its production must be higher than that of genuinely efficient firms. Nevertheless, so long as owners of equity capital do not have to be compensated, the firm can go on indefinitely without being forced to liquidate. To prevent the market value of equity becoming zero, the firm may pay very small, constant dividends, without changing the basic feature of the model discussed above. It may be possible to construct a much more realistic and plausible model of a Japanese firm in which competing interests of participants are described carefully. So long as the price attributed to the contribution of one or more factors by the management is significantly different from their market price, however, the distortion considered above must be present, and the allocation of resources in the whole economy cannot be efficient.

\section{Conclusion}

In this chapter we have explored reasons why the market value of equity of corporations in Japan has not increased to reflect their accumulation of capital. One consequence of this situation is that the Japanese economy has been facing a condition of insufficient demand, since households incur considerable capital losses in their corporate equity holdings and thus reduce their consumption. This condition does not seem to have any prospect of resolving itself, unless a way can be found to transfer a substantial amount of resources from corporations to households via substantially increased dividend payments.

In the standard model of corporate finance, the present value of future dividend payments, allowing for the risk involved, determines the market value of equity. In equilibrium that value is roughly equal to the value of accumulated capital, allowing for a variety of special conditions. This may be viewed as a consequence of nearly rational 
behavior on the part of management and the reasonably efficient functioning of markets for factors and output. Although real market conditions may never be in equilibrium, we expect that there will be general tendencies to move toward the equilibrium. Data covering a large number of corporations and a long period of time should point to where the equilibrium position is likely to be.

The data for Japan do not resemble such a picture. The historical pattern of net dividend payments is nearly constant in nominal terms over time, and has nothing to do with the accumulation of capital by corporations. Typical market participants therefore can only assume that this pattern is likely to continue. Such an expectation can support only a very low level of the value of equity, and this distorts saving behavior.

During the high-growth era, Japanese firms had some justification for retaining and re-investing earnings. By the early 1990s, however, readily available technologies enabling increased productivity had become limited, and Japan's labor cost had reached approximately the same level, or perhaps even above, that of the United States. To maintain balance between aggregate demand and aggregate supply, therefore, the savings rate must become lower, and consumption demand must be expanded.

What can be done achieve this and thus remove a serious impediment to growth? Changes in corporate governance to give equity holders the capacity to deal with management on more equal terms must be considered. A complete reform of the accounting system also would be helpful. The government should consider changing the corporate profit tax system. The reformed tax system would encourage corporations to pay out funds when sufficiently profitable internal investment opportunities are not available.

We have estimated the "lost" wealth and financial cost to Japan of the market valuation discrepancy. The household sector's "lost" wealth is presented in the bottom panel of Table 2. Essentially, the calculation turns on estimating what the value of equity would be if Tobin's q were equal to one (a more detailed explanation is given in Appendix 3, available at $<$ www.nber.org/data-appendix/ando_et_al $>$ ).

At the end of 1998, the total value of net equity outstanding for all corporations (column 3) would have been 750 trillion yen (instead of the actual 171 trillion), of which 
the household sector would have owned 475 trillion yen (rather than its actual 81 trillion). This is 395 trillion yen in "lost" wealth.

If the marginal propensity to consume out of net worth is 0.04 , a reasonable value in terms of available estimates, consumption could have been larger by almost 16 trillion yen without any multiplier effect. With a very small multiplier of 1.5, additional consumption could have been more than 23 trillion yen. That would have been enough to put the Japanese economy back into full employment. 


\section{References}

Ando, A., Hancock, J., and Sawchuk, G., (1997), "Cost of Capital for the United States, Japan, and Canada: An Attempt at Measurement Based on Individual Company Records and Aggregate National Accounts Data", in Financing Growth in Canada, P.J.N. Halpern, editor, University of Calgary Press, Calgary, Canada.

Ando, A. (2002a), "Missing Household Saving and Valuation of Corporations: Inquiry into Japanese National Accounts I", Journal of the Japanese and International Economies 16 (2), pp. 147-176.

Bank of Japan (2002), Financial and Economic Statistics Monthly, 41, August, Tokyo.

Dekle R. (1994), "Market Value Estimates of Japanese Saving and Comparisons with the US: can the Capital Gains to Land be included in 'Saving'? ", Japan and the World Economy 6, pp. 27-44.

ESRI (Economic and Social Research Institute, Cabinet Office, Government of Japan) (2001), Annual Report on National Accounts, Tokyo.

EPA (Economic Planning Agency, Government of Japan) (2000a), Annual Report on National Accounts, Tokyo.

EPA (Economic Planning Agency, Government of Japan) (2000b), Explanation of Estimation Procedure according to 1993 SNA (preliminary Edition), Tokyo

EPA (Economic Planning Agency, Government of Japan) (1978), Shin Kokumin Keizai Keisan no Mikata, Tsukaikata (Guide for users of New National Accounts), Tokyo.

Gordon, Roger, and Burton Malkiel (1981), "Corporate Finance", in How Taxes Affect Economic Behavior, edited by J. Pechman and H. Aaron, Brookings Institution. 
Hayashi, F. (1986), “Why Is Japan's Saving Rate Apparently So High?”, NBER Macroeconomics Annual, MIT Press, Cambridge, MA, pp. 147-210.

Hayashi, F. and T. Inoue (1991), "The Relation between Firm Growth and Q with Multiple Goods: Theory and Evidence from Panel Data on Japanese Firms," Econometrica 59, May, pp. 731-753.

Hulten, C., and F. Wykoff (1981), "The Measurement of Economic Depreciation", in Depreciation, Inflation and the Taxation of Income from Capital, edited by C. Hulten, Urban Institute, Washington, D.C, pp. 81-125.

Murata, K. (1999), “The Consumption Function in Japan”, Oxford D. Phil. Thesis

Ogawa, K., Kitasaka S., Yamaoka H. and Y. Iwata (1996), “An empirical Re-evaluation of the Wealth Effect in Japanese Household Behavior", Japan and the World Economy 8, pp. 423-442.

Takayama, N. (1992), "The Greying of Japan: an Economic Perspective on Public Pensions", Tokyo: Kinokuniya, and Oxford: Oxford Univ. Press 
Table 1

HOUSEHOLD SECTOR SAVING AND NET WORTH IN 1990 Prices, 1971-1998

(trillion yen)

A.1 Reproducible Tangible Assets ${ }^{2}$

A.2 Flow

A.3 Reconciliation ${ }^{3}$

B.1 Non Reproducible Tangible Assets ${ }^{2}$

B.2 Flow

B.3 Reconciliation ${ }^{3}$

C.1 Net Financial Assets (excl. equity shares)

C.2 Flow

C.3 Reconciliation excl. inflation loss ${ }^{4}$

C.4 Inflation Gain (Loss)

D.1 Equity

D.2 Flow

D.3 Reconciliation

\section{E.1 Net Worth $=$ A. $1+B .1+C .1+D .1$}

E. 2 Flow = A. $2+$ B. $2+$ C. $2+$ D. 2 = F. $1+$ F $.2+F .3$

E.3 Reconciliation excl. inflation loss on net

financial assets $=$ A. $3+$ B. $3+$ C. $3+$ D. 3

E.4 Inflation Gain (Loss) $=$ C. 4

F.1 Saving

F.2 Net Capital Transfers

F.3 Statistical Discrepancy

\section{EXCLUDING LAND}

\section{E.1A Net Worth $=$ A.1+C.1+D.1}

E. 2 A Flow $=$ A. $2+$ C. $2+D .2=F .1 A+F .2+F .3$

E.3A Reconciliation excl. inflation loss on net financial assets $=$ A.3+C.3+D.3

E.4A Inflation Gain (Loss) $=$ C. 4

F.1A Saving = F.1 - B.2

\begin{tabular}{|c|c|c|c|}
\hline 1971-1979 & $1980-1990$ & 1991-1998 & Accumulated \\
\hline 129.0 & 66.0 & 23.2 & 218.2 \\
\hline 131.3 & 94.1 & 46.0 & 271.4 \\
\hline-2.3 & -28.1 & -22.8 & -53.3 \\
\hline 227.5 & 982.3 & -538.5 & 671.3 \\
\hline-50.8 & -84.3 & -24.1 & -159.1 \\
\hline 278.3 & $1,066.6$ & -514.4 & 830.4 \\
\hline 112.9 & 259.1 & 235.3 & 607.3 \\
\hline 216.6 & 339.2 & 273.9 & 829.6 \\
\hline-1.5 & -5.9 & 1.7 & -5.7 \\
\hline-102.2 & -74.2 & -40.2 & -216.6 \\
\hline 21.5 & 109.8 & -93.1 & 38.2 \\
\hline 5.7 & 2.1 & -9.1 & -1.4 \\
\hline 15.9 & 107.7 & -84.0 & 39.6 \\
\hline 490.9 & $1,417.2$ & -373.2 & $1,534.9$ \\
\hline 302.8 & 351.0 & 286.7 & 940.5 \\
\hline 290.2 & $1,140.3$ & -619.6 & 811.0 \\
\hline-102.2 & -74.2 & -40.2 & -216.6 \\
\hline 322.9 & 360.6 & 301.6 & 985.1 \\
\hline-6.4 & -15.9 & -20.4 & -42.7 \\
\hline-13.7 & 6.4 & 5.5 & -1.9 \\
\hline 263.4 & 434.9 & 165.4 & 863.7 \\
\hline 353.6 & 435.3 & 310.8 & $1,099.7$ \\
\hline 12.0 & 73.7 & -105.2 & -19.4 \\
\hline-102.2 & -74.2 & -40.2 & -216.6 \\
\hline 373.7 & 444.9 & 325.7 & $1,144.2$ \\
\hline
\end{tabular}

1 The household sector includes non-profit institutions. SNA68 and our estimate of reproducible tangible assets are used. Constant prices were obtained using the deflator for total private consumption expenditure.

Social Research Institute, Cabinet Office, the Japanese Government). Corresponding adjustments were made to the investment in land and the reconciliation accounts of reproduci

3 Including inflation loss

4 For net financial assets, losses to creditors are gains to debtors, so the effects of general inflation are reported explicitly rather than as part of reconciliation. (See discussion in the text.)

Also see Box 1 for additional information on the data

Source: EPA, Annual Report on National Accounts 2000, p 86-89, 326-31. 
Table 2

SECTORAL BALANCE SHEET, 1998 year-end, SNA93 Data ${ }^{1}$

(trillion yen)

(a) Reproducible Physical Assets

(b) Non-Reproducible Physical Assets

(c) Total Physical Assets (a) + (b)

(d) Gross Financial Assets Excl. Equity

(e) Gross Liabilities Excl. Equity

(f) Net Financial Position (d) + (e)

(g) Balance excluding Equity (c) + (f)

(Accounting net worth (net) for corporate sector)

(h) Gross Equity Oustanding (Market Value)

(i) Gross Equity Owned (Market Value)

(j) Net Equity Position (i) + (h)

(k) Market Valuation Discrepancy -[(g) + (j)]

(1)

$(1)$
Non-Financial

(2)

cial

(3)

\section{0 \\ 433.2}

\section{0}

22.1

$1,154.3$

$$
45.0
$$

(1) $+(2)$

(4)

Government

Households

(6)

576.0
-977.9
-401.9

$2,854.9$

$-2,902.1$

$-47.2$

744.0

455.3

$1,199.3$

325.9

162.1

487.9

$3,430.9$

$-3,879.9$

$-449.1$

300.8

$-549.6$

$-248.8$

752.4

$-2.2$

750.2

239.1

344.8

$1,083.4$

$1,428.1$

$1,284.0$

$-415.1$

868.9

$2,297.0$

$\begin{array}{llll}-329.9 & -69.0 & -399.0 & -10.2\end{array}$

$\begin{array}{llll}89.3 & 138.6 & 227.9 & 62.8\end{array}$

$-240.6$

69.6

$-171.0$

52.6

80.7

80.7

37.9

$-511.8$

$-67.4$

$-579.2$

(I) Household and Government Accounting Net Worth including Equity $(\mathrm{g})+(\mathrm{i})$

(II) Net Worth excluding Value of Land (Households Only)

(m) Tobin's Average q [-(j) - (f)]/(c)

(n) Disposable Income (Households Only)

360.7

\section{HYPOTHETICAL EQUILIBRIUM PATTERN ${ }^{3}$}

(h') Gross Equity Oustanding (Market Value)

(i') Gross Equity Owned (Market Value)

(j') Net Equity Position (=g)

$-1,176.6$
424.2

424.2
-752.4

-658.4
658.5
2.2

$-1,895.1$

$1,082.7$

$-750.2$
$-10.2$
62.8

52.6

$-$
474.8

474.8

$2,771.8(7.68)^{2}$ $(1,688.4)(4.68)^{2}$

(II') Net Worth excluding Value of Land (Households Only)

2001.

2 Figures in parentheses are ratios to disposable income.

3 Assumptions used for the hypothetical equilibrium pattern

(1) $i^{\prime}=i, h^{\prime}=h$ and $j^{\prime}=j$ for the government (column 4)

(2) $\mathrm{j}^{\prime}=\mathrm{g}$ for corporations (columns (1), (2) and (3)).

(3) $i^{\prime}=j^{\prime \prime *}(\mathrm{i} / \mathrm{j})$ in column (3). Thus $\mathrm{h}^{\prime}=\mathrm{j}^{-}-\mathrm{i}^{\prime}$ in column (3)

(4) In column (1), i'(1)=i'(3)*[i(1)/[i(1)+i(2)]]. In column (2), i'(2)=i'(3)*[i(2)/[i(1)+i(2)]]. In addition, $h^{\prime}(1)=j^{\prime}(1)-i^{\prime}(1)$ and $h^{\prime}(2)=j^{\prime}(2)-i^{\prime}(2)$

(5) $j^{\prime}(5)+j^{\prime}(6)=j^{\prime}(3)-j^{\prime}(4)$. In column (5), j'(5)=[j'(3)-j'(4)]*[i(5)/[j(5)+j(6)]]. In column $(6), j^{\prime}(6)=\left[j^{\prime}(3)-j^{\prime}(4)\right]^{*}[j(6) /[j(5)+j(6)]]$. 
Table 3

Distribution of GDP in the Non-Farm Private Business Sector, Excluding Housing, 1970-98

\begin{tabular}{|c|c|c|c|c|c|c|c|c|c|c|}
\hline \multirow{4}{*}{ Year } & \multicolumn{5}{|c|}{ Absolute Amounts } & \multicolumn{4}{|c|}{ Percentage of GDP } & \multirow{3}{*}{$\begin{array}{c}\text { (10) } \\
\text { Depreciation } \\
\text { as \% of capital } \\
\text { stock }\end{array}$} \\
\hline & (1) & (2) & (3) & (4) & (5) & (6) & (7) & (8) & (9) & \\
\hline & $\mathrm{GDP}^{1}$ & Depreciation $^{2}$ & $\begin{array}{l}\text { Compensation of } \\
\text { Employees }\end{array}$ & $\begin{array}{l}\text { Operating } \\
\text { Surplus }\end{array}$ & $\begin{array}{l}\text { Capital } \\
\text { Stock }^{3}\end{array}$ & Depreciation & $\begin{array}{l}\text { Compensation } \\
\text { of Employees }\end{array}$ & $\begin{array}{l}\text { Operating } \\
\text { Surplus }\end{array}$ & Capital Stock & \\
\hline & \multicolumn{5}{|c|}{ Part A: United States (billion dollars) } & & & & & \\
\hline 1970 & 687.7 & 65.0 & 460.1 & 162.6 & $1,013.2$ & 9.5 & 66.9 & 23.6 & 147.3 & 6.4 \\
\hline 1980 & $1,926.7$ & 226.1 & $1,257.8$ & 442.8 & $3,202.6$ & 11.7 & 65.3 & 23.0 & 166.2 & 7.1 \\
\hline 1991 & $3,995.7$ & 512.5 & $2,536.9$ & 946.3 & $6,622.7$ & 12.8 & 63.5 & 23.7 & 165.7 & 7.7 \\
\hline 1995 & $5,019.2$ & 630.2 & $3,117.1$ & $1,271.9$ & $7,731.5$ & 12.6 & 62.1 & 25.3 & 154.0 & 8.2 \\
\hline \multirow[t]{2}{*}{1998} & $6,093.0$ & 759.6 & $3,757.1$ & $1,576.3$ & $9,006.8$ & 12.5 & 61.7 & 25.9 & 147.8 & 8.4 \\
\hline & \multicolumn{5}{|c|}{ Part B: Japan, with National Account Estimates ${ }^{4}$ (trillion yen) } & & & & & \\
\hline 1971 & 60.4 & 7.6 & 31.2 & 21.6 & 50.2 & 12.6 & 51.6 & 35.8 & 83.1 & 15.1 \\
\hline 1980 & 176.7 & 26.7 & 105.1 & 44.9 & 213.1 & 15.1 & 59.5 & 25.4 & 120.6 & 12.5 \\
\hline 1990 & 314.7 & 52.0 & 190.1 & 72.6 & 419.9 & 16.5 & 60.4 & 23.1 & 133.4 & 12.4 \\
\hline 1995 & 343.7 & 64.1 & 226.1 & 53.5 & 548.0 & 18.6 & 65.8 & 15.6 & 159.4 & 11.7 \\
\hline \multirow[t]{2}{*}{1998} & 341.9 & 69.4 & 231.2 & 41.3 & 596.4 & 20.3 & 67.6 & 12.1 & 174.4 & 11.6 \\
\hline & \multicolumn{5}{|c|}{ Part C: Japan, with Our Estimates ${ }^{5}$ (trillion yen) } & & & & & \\
\hline 1971 & 60.4 & 4.9 & 31.2 & 24.3 & 61.7 & 8.1 & 51.6 & 40.3 & 102.1 & 7.9 \\
\hline 1980 & 176.7 & 21.6 & 105.1 & 50.0 & 276.2 & 12.2 & 59.5 & 28.3 & 156.3 & 7.8 \\
\hline 1990 & 314.7 & 43.1 & 190.1 & 81.4 & 523.3 & 13.7 & 60.4 & 25.9 & 166.3 & 8.2 \\
\hline 1995 & 343.7 & 54.9 & 226.1 & 62.7 & 678.3 & 16.0 & 65.8 & 18.3 & 197.4 & 8.1 \\
\hline 1998 & 341.9 & 58.2 & 231.2 & 52.6 & 703.8 & 17.0 & 67.6 & 15.4 & 205.8 & 8.3 \\
\hline
\end{tabular}

GDP for Japan reflects our estimates of the distribution of imputed banking services among sectors. Imputed banking services were calculated based on interest flows and operating surplus. The US figures incorporate the distribution estimated by the BEA.

1 GDP less indirect business taxes.

2 For the United States, depreciation is with a CCAdj (as discussed under "Depreciation" in the text). For Panel B we calculated an adjustment to make the National Accounts series current-cost, following a methodology similar to the work of Hayashi (1986)

3 Capital stock is as of the beginning of the year.

4 National Accounts estimates of reproducible fixed assets are used.

5 Our estimates of reproducible fixed assets used.

Source: For the United States, from Bureau of Economic Analysis web site <bea.doc.gov>. For Japan, EPA, Annual Report on National Accounts 2000, p 168-79, 390. 
Table 4

Corporate Sector, Saving and Net Dividends Paid, SNA93 Data (trillion yen)

\begin{tabular}{|c|c|c|c|c|c|c|c|c|c|}
\hline Part A: Non-Financia & $\begin{array}{c}1990 \\
\text { rations }\end{array}$ & 1991 & 1992 & 1993 & 1994 & 1995 & 1996 & 1997 & 1998 \\
\hline A. Saving $A^{1}$ & 7.41 & 4.42 & 2.15 & 3.18 & 3.25 & 5.53 & 10.27 & 14.69 & 10.15 \\
\hline B. Saving $B^{2}$ &..-- & -4.40 & -7.90 & -7.95 & -7.60 & -9.11 & 2.19 & 5.39 & 0.72 \\
\hline C. Saving $C^{3}$ & 10.33 & 6.15 & 2.88 & 2.61 & 2.96 & 6.25 & 14.63 & 18.11 & 12.39 \\
\hline D. Net Dividends Paid & 2.78 & 2.74 & 2.61 & 2.62 & 2.39 & 2.88 & 2.50 & 2.56 & 2.25 \\
\hline \multicolumn{10}{|c|}{ Part B: Financial Institutions } \\
\hline E. Saving $A^{1}$ & 6.17 & 6.89 & 6.05 & 5.67 & 4.69 & 6.58 & 8.63 & 9.64 & 10.32 \\
\hline F. Saving $B^{2}$ &..-- & 7.67 & 7.43 & 7.14 & 6.61 & 8.52 & 10.39 & 11.34 & 11.78 \\
\hline G. Saving $C^{3}$ & 6.96 & 7.29 & 6.90 & 6.51 & 5.96 & 8.06 & 9.84 & 10.80 & 11.16 \\
\hline H. Net Dividends Paid & -0.33 & -0.36 & -0.34 & -0.32 & -0.26 & -0.34 & -0.41 & -0.45 & -0.41 \\
\hline
\end{tabular}

1 Using National Accounts depreciation (thus, at historical cost). 2 Using National Accounts depreciation and CCAdj

3 Using our estimates of depreciation (based on Hulten-Wykoff service lives and current-cost).

Source : ESRI, Annual Report on National Accounts, 2001, pp. 94-97, 500-509. 
Table 5

DIVIDENDS OF NON-FINANCIAL INCORPORATED ENTERPRISES, SNA68 DATA (trillion yen)

$\begin{array}{lcccc}\text { Year } & \text { Dividends Paid } & \text { Dividends Received } & \text { Net Dividends Paid } & \text { Sector GDP } \\ 1970 & & & & \\ 1971 & 1.521 & 0.501 & 1.020 & 58.2 \\ 1972 & 1.622 & 0.529 & 1.092 & 63.7 \\ 1973 & 1.782 & 0.585 & 1.197 & 72.8 \\ 1974 & 2.233 & 0.770 & 1.463 & 89.2 \\ 1975 & 2.579 & 0.925 & 1.655 & 104.9 \\ 1976 & 2.424 & 0.858 & 1.566 & 113.3 \\ 1977 & 2.477 & 0.871 & 1.606 & 127.9 \\ 1978 & 2.334 & 0.871 & 1.464 & 141.5 \\ 1979 & 2.729 & 0.975 & 1.754 & 156.1 \\ 1980 & 2.914 & 1.027 & 1.887 & 170.2 \\ 1981 & 3.190 & 1.174 & 2.016 & 185.6 \\ 1982 & 3.502 & 1.289 & 2.213 & 199.8 \\ 1983 & 3.291 & 1.210 & 2.081 & 210.1 \\ 1984 & 3.378 & 1.216 & 2.161 & 218.4 \\ 1985 & 3.453 & 1.250 & 2.203 & 233.3 \\ 1986 & 3.698 & 1.604 & 2.095 & 249.2 \\ 1987 & 3.845 & 1.842 & 2.003 & 258.5 \\ 1988 & 4.177 & 2.991 & 1.186 & 270.6 \\ 1989 & 4.420 & 3.666 & 0.754 & 289.5 \\ 1990 & 6.465 & 5.412 & 1.054 & 311.6 \\ 1991 & 5.597 & 5.451 & 0.146 & 337.2 \\ 1992 & 5.744 & 5.647 & 0.097 & 361.7 \\ 1993 & 5.599 & 5.394 & 0.205 & 370.2 \\ 1994 & 5.668 & 5.117 & 0.550 & 369.1 \\ 1995 & 5.265 & 4.468 & 0.798 & 367.1 \\ 1996 & 5.709 & 4.325 & 1.384 & 370.7 \\ 1997 & 5.899 & 2.918 & 2.981 & 382.4 \\ 1998 & 5.855 & 3.240 & 2.615 & 386.7 \\ & 5.691 & 3.231 & 2.460 & 374.1\end{array}$

1. Private business GDP, excluding the agriculture, housing, and financial sectors.

Source : EPA, Annual Report on National Accounts, 2000, pp. 72-73. See notes for Table 3 for calculation of GDP. 
Table 6

DIVIDENDS PAID AND RECEIVED BY CORPORATIONS, SNA 93 DATA ${ }^{1}$ (trillion yen)

\begin{tabular}{|c|cc|cc|c|}
\hline \multirow{2}{*}{ Year } & \multicolumn{2}{|c|}{ NON-FINANCIAL } & \multicolumn{2}{|c|}{ FINANCIAL } & TOTAL $^{2}$ \\
& Paid & Received & Paid & Received & \\
\hline & & & & & \\
1990 & 4.971 & 2.193 & 0.918 & 1.251 & 2.445 \\
1991 & 5.090 & 2.347 & 0.837 & 1.195 & 2.385 \\
1992 & 4.918 & 2.311 & 0.794 & 1.139 & 2.262 \\
1994 & 4.960 & 2.336 & 0.857 & 1.172 & 2.309 \\
1995 & 4.536 & 2.149 & 0.768 & 1.031 & 2.123 \\
1996 & 4.942 & 2.057 & 0.717 & 1.061 & 2.540 \\
1997 & 5.040 & 2.539 & 0.700 & 1.115 & 2.087 \\
1998 & 5.100 & 2.544 & 0.718 & 1.167 & 2.108 \\
\end{tabular}

1. Includes non-financial and financial corporations. Excludes withdrawals of income from quasi corporations. 2. Net payments

Source: ESRI, Annual Report on National Accounts, 2001, pp. 94-97 
Table 7

Corporate Sector Saving and Net Worth in 1990 Prices, 1971-1998', SNA68

(trillion yen)

A.1 Reproducible Tangible Assets ${ }^{2}$

A.2 Flow

A.3 Revaluation

B.1 Non Reproducible Tangible Assets ${ }^{2}$

B.2 Flow

B.3 Revaluation

C.1 Net Financial Assets (excl. equity shares)

C. 2 Flow

C.3 Reconciliation excl inflation loss ${ }^{3}$

C.4 Inflation Gain

D. 1 Equity (Accounting) $=\mathrm{A} \cdot 1+\mathrm{B} \cdot 1+\mathrm{C} .1^{4}$

D. 2 Flow $=$ A. $2+$ B. $2+$ C. 2 = E. $1+$ E. $2+$ E. $3+$ E. 4

D. 3 Reconciliation excl. inflation loss on net financial assets $=$ A. $3+$ B. $3+$ C. 3

D.4 Inflation Gain = C.4

D.5 Equity (Market) ${ }^{4}$

D.6 Market Valuation Discrepancy ${ }^{4}$

E.1 Saving

E.2 Net Capital Transfers

E.3 Statistical Discrepancy

E.4 Net Equity Transactions ${ }^{5}$

$\begin{array}{cc}1971-1979 & 1980-1990 \\ 167.3 & 193.9 \\ 212.6 & 278.2 \\ -45.3 & -84.3 \\ & \\ 86.2 & 519.4 \\ 51.3 & 68.9 \\ 34.9 & 450.5 \\ & \\ -52.6 & -209.3 \\ -158.1 & -307.1 \\ 4.9 & 46.5 \\ 100.6 & 51.3 \\ & \\ 200.8 & 504.0 \\ 105.7 & 40.1 \\ -5.5 & 412.7 \\ 100.6 & 51.3 \\ & \\ 21.7 & 120.7 \\ 179.1 & 383.3 \\ 81.2 & 105.0 \\ 13.5 & 17.7 \\ 11.5 & -13.2 \\ -0.4 & -69.4\end{array}$

$\begin{array}{cc}1991-1998 & \text { Accumulated } \\ 91.7 & 452.9 \\ 211.7 & 702.6 \\ -120.1 & -249.7 \\ & \\ -284.3 & 321.3 \\ -1.4 & 118.8 \\ -283.0 & 202.4 \\ & \\ -40.5 & -302.4 \\ -75.6 & -540.8 \\ 4.3 & 55.7 \\ 30.8 & 182.6 \\ & \\ -233.1 & 471.7 \\ 134.8 & 280.6 \\ -398.7 & 8.4 \\ 30.8 & 182.6 \\ & \\ -72.7 & 69.7 \\ -160.4 & 402.0 \\ 85.6 & 271.9 \\ 49.3 & 80.4 \\ -14.3 & -16.0 \\ 14.1 & -55.6 \\ & \\ & \\ & \end{array}$

1 The corporate sector can be decomposed into non-financial corporate enterprises and financial institutions. It includes public enterprises as well as private corporations, and these are an especially large part of the financial institutions sector. Our

2 Gross fixed capital formation has been reduced by the amount of investment in land improvement using data provided by Mr Mitsuo Hosen of the ESRI. Corresponding adjustments were made to the investment in land and the reconciliation accounts of reproduci

3 For financial assets, losses to creditors are gains to debtors, so the effects of general inflation are reported explicitly rather than as part of reconciliation. (See Box 1.)

4 Accounting equity (D1) differs from the market value of equity (D5) by the market valuation discrepancy (D6).

5 Equals new issues of equity minus acquisitions of equity. A minus sign indicates corporations were net purchasers of equity. During the most of the period non-financial corporations were net sellers of equity but financial corporations were major purch

Also see Box 1 for additional information on the data.

Source: EPA, Annual Report on National Accounts 2000, p 80-83, 322-25. 
Table 8

Rate of Return on Corporations

(annual percent rates)

\begin{tabular}{|c|c|c|c|c|c|}
\hline \multirow[b]{3}{*}{ Period Average $^{1}$} & (1) & $(2)$ & (3) & (4) & (5) \\
\hline & \multicolumn{2}{|c|}{ Return on Capital ${ }^{2}$} & \multicolumn{3}{|c|}{ Market Rate of Return } \\
\hline & $\begin{array}{c}\text { Non Financial } \\
\text { Corporations } \\
\end{array}$ & Business Sector ${ }^{3}$ & Ordinary Income ${ }^{4}$ & Capital Gains $^{5}$ & Total Return ${ }^{6}$ \\
\hline $1971-1980$ & 7.36 & 11.69 & 8.05 & -6.50 & 1.58 \\
\hline $1981-1990$ & 5.55 & 7.30 & 4.94 & 3.54 & 8.56 \\
\hline 1991-1998 & 3.67 & 5.04 & 1.82 & -2.87 & -1.06 \\
\hline 1971-1998 & 5.18 & 7.54 & 4.71 & -1.88 & 2.91 \\
\hline
\end{tabular}

1 Geometric average

2 Operating surplus adjusted for rent, depreciation and imputed banking services divided by the sum of reproducible assets and land 3 Includes households, unincorporated enterprises and corporations.

4 Net interest and net dividends paid divided by the sum of net equity outstanding and net financial liabilities. That is, payments to owners and creditors as a percentage of the capital they provide to the firm.

5 Nominal capital gains minus inflation loss divided by the sum of net equity outstanding and net financial liabilities.

6 Geometric average. Due to the particular averaging procedure adopted, the sum of columns (3) and (4) is slightly different from column (5)

Source: EPA, Annual Report on National Accounts, 2000, pp. 79-89, 248-249, 322-337, 390-391 and Appendix 1. 